\title{
ESENSI KEPEMIMPINAN DALAM PERSPEKTIF PERJANJIAN LAMA
}

\section{Wilianus Illu}

\section{PENDAHULUAN}

Kepemimpinan adalah bagian yang sangat penting dalam kehidupan manusia. Karena manusia adalah makhluk ciptaan Tuhan yang sangat berbeda dengan makhluk ciptaan Tuhan lainnya. V.M. Siringo-Ringo menjelaskan bahwa manusia diberi perhatian khusus dalam penciptaan dengan memberi gelar kemuliaan makhluk utama atau mahkota segala makhluk. ${ }^{1}$

Anthony A. Hoekema menegaskan bahwa manusia bukan sekedar sebuah ciptaan saja melainkan satu pribadi. Menjadi satu pribadi, berarti memiliki suatu bentuk kemandirian, bukan mutlak tetapi relative. Menjadi satu pribadi berarti mampu membuat keputusan, menetapkan tujuan, dan bergerak ke arah tujuan-tujuan itu. Yang berarti manusia memiliki kebebasan. ${ }^{2}$

Selanjutnya Loius Leahy menambahkan bahwa manusia yang telah diciptakan oleh Tuhan memiliki pengetahuan yang lebih dari ciptaan-ciptaan lainnya, dan berhak untuk berkuasa terhadap ciptaan Tuhan lainnya. ${ }^{3}$ Surbakti mempertajam "salah satu kelebihan manusia jika dibandingkan makhluk atau organisme lainnya adalah memiliki hati nurani untuk mempertimbangkan baikburuknya sebuah keputusan bagi seorang pemimpin. ${ }^{4}$

Petrus Octavianus mengutip pendapat Dr. J.Robert Clinton, dan menuangkan dalam buku Alih Generasi Kepemimpinan dengan melihat manusia sebagai pemimpin dalam dua dimensi. Dimensi pertama adalah ilmu kepemimpinan bagi seorang pemimpin, dan dimensi kedua adalah pemimpin

\footnotetext{
${ }^{1}$ V.M Siringo-ringo, Theologi Perjanjian Lama, Sejarah, Metode dan Pokok-pokok Theology Perjanjian Lama, (Yogyakarta: Yayasan Andi, 2013), 35-36

2 Anthony A. Hokema, Manusia Ciptaan Menurut Gambar Allah, (Surabaya: Momentum, 2008), 8

${ }^{3}$ Louis Leahy, Manusia Sebuah Misteri Sintesa Filosofis tentang Makhluk Paradoksal, (Jakarta: PT Gramedia, 1985), 55

${ }^{4}$ Drs. E.B. Surbakti, Manajemen dan Kepemimpinan Hati Nurani, (Jakarta: PT Gramedia, 2012), vii
} 
itu sendiri, bagaikan mata uang yang mempunyai dua sisi, dan tidak bisa dipisahkan karena satu benda yang punya fungsi yang sama. ${ }^{5}$

Dari sudut pandang ini, maka secara hakekat manusia telah diberikan tanggungjawab sepenuhnya terhadap ciptaan lainnya. Tanggungjawabnya itu adalah bagian dari kepemimpinan yang Tuhan percayakan kepada manusia. Maka sadar atau tidak sadar bahwa setiap manusia adalah pemimpin. Pemimpin yang dimaksudkan adalah pemimpin yang memimpin sesama manusia dalam garis Firman Allah. Namun faktanya bahwa setiap pemimpin yang memimpin pada zamannya sering membuat persoalan-persoalan yang merugikan pihak lain. Baik kerugian yang sifatnya internal maupun eksternal, serta dampaknya pun sangat berbahaya.

Sering kita mendengar berita tentang seorang pemimpin, bahwa ada pemimpin yang baik, kurang baik, cukup baik bahkan tidak baik. Ada pemimpin yang otoriter, diktator, bahkan maunya menang sendiri, apalagi seorang pemimpin yang telah memiliki gelar yang tinggi dan kecenderungannya adalah kurang mau mendengar nasihat orang yang belum punya kesempatan meraih pendidikan yang tinggi. Bahkan menyapa pun tidak dihiraukan oleh pemimpin tersebut. Ocehan-ocehan ini muncul oleh karena melihat dan menyaksikan fakta-fakta beberapa pemimpin masa kini yang cenderung tidak melakukan prinsip dan nilai-nilai positif dalam kepemimpinannya itu sendiri.

Pemimpin adalah cermin. Tentu yang memperhatikan bukanlah sekelompok orang saja, melainkan semua orang yang ada di sekitarnya, baik bahasa tubuhnya, bahasa lisannya, bahasa tulisannya, bahkan sampai pada hubungan diplomatis terhadap sesama pun turut diperhatikan. Itu sebabnya tidak mudah bagi seorang pemimpin yang mau diperbaharui seperti membalik telapak tangan, melainkan mengalami dan melewati berbagai proses sebagai perwujudan dari kepemimpinannya.

Proses tersebut membutuhkan kedewasaan hati, kedewasaan pikiran, kedewasaan respon dalam memilah dan memilih sejumlah ocehan, baik itu positif ataupun negative. Dibutuhkan juga kedewasaaan bagi seorang pemimpin dalam mengimplementasikan nilai-nilai positif pada konteks kekinian.

Adapun pernyataan di atas ingin menjelaskan bahwa seorang pemimpin pada masa kini telah diperhadapkan dengan sejumlah persoalan yang ada, yang sedang terjadi dan akan terus berlangsung dalam kehidupan seorang pemimpin.

\footnotetext{
${ }^{5}$ Petrus Octavianus, Alih Generasi dan Kepemimpinan dalam Garis Firman Allah (Batu: Petrus Octavianus Institut, t.t. ), 5
} 
Jika hal itu tidak dipertimbangkan dan diantisipasi dengan baik oleh sang pemimpin, maka akan berdampak buruk bagi dirinya sebagai pemimpin dan juga bagi umat atau orang lain yang telah dipimpinnya. Itu sebabnya berbagai perspektif dari sejumlah kalangan belakangan ini menyebutkan bahwa kepemimpinan masa sekarang, mulai dari aras Nasional sampai ke desa-desa telah mengalami kemunduran nilai-nilai yang positif. Alias mengalami krisis kepemimpinan. ${ }^{6}$ Dunia yang kita tinggali hari ini berada dalam krisis kepemimpinan global. Krisis kepemimpinan global berarti semua lini atau jenis bidang apa saja yang telah dipandu oleh pemimpin semuanya telah mengalami krisis kepemimpinan. Mengapa demikian? Oleh karena adanya kemundurankemunduran nilai yang dilakukan oleh pemimpin karena hilang keseimbangan. Begitu diberikan kepercayaan sebagai pemimpin lebih mementingkan kehidupan individunya, kelompoknya dan masa yang mendukungnya sekalipun kelompok atau masanya belum tentu memiliki kompetensi dalam hal kepemimpinan. Sisi lain bagi pemimpin karena baru memimpin sehingga kecenderungan muncullah kesombongan, dan hal itu tidak disadarai dalam hidupnya. $^{7}$

Fakta tersebut menjadi tantangan baru bagi pemimpin masa kini, apa yang harus diperbuat oleh pemimpin masa kini? Apakah pemimpin diam seribu bahasa? Ataukah pemimpin hanya melihat dan mengangguk-anggukkan kepala dan tidak melakukan apa-apa dalam situasi kepemimpinan lain yang ada? Ataukah telah melakukan pelayanan sebagai pemimpin, namun mengekspos persoalan tersebut kepada orang lain yang tidak perlu mengetahuinya? Atau apakah pemimpin dengan hati yang tulus mengadakan upaya pendekatan demi merestorasi kepemimpinan masa kini?

Sejumlah pertanyaan yang ada bagi penulis adalah pertanyaan yang mendasar bagi kepemimpinan yang perlu mendapat perhatian serius terhadap kepemimpinan pada masa kini. Untuk itu setiap pertanyaan di atas akan terjawab pada pembahasan berikutnya.

${ }^{6}$ Sendjaya, Kepemimpinan (Konsep, Karakter, Kompetensi) Kristen Menjadi Pemimpin Kristen yang Efektif di tengah Tantangan Arus Zaman, (Yogyakarta: Kairos Books, 2004), 16-17

${ }^{7}$ Ibid, 15 


\section{DEFINISI}

Istilah definisi adalah sebuah kata yang perlu mendapat perhatian khusus karena dari definisilah kita akan mengetahui dan menyusun sebuah tulisan ini secara sistematis dan bisa dipertanggungjawabkan. Maka istilah definisi adalah suatu kata yang menjelaskan tentang pengertian dari sebuah kata yang belum diketahui dan dipahami secara umum. Karena itu pada definisi ini akan ditemukan pengertian kata dari asal usul kata, juga pengertian secara umum, dengan tujuan agar memudahkan kita sebagai pembaca memahami alur sebuah tulisan dengan baik.

\section{$\underline{\text { Esensi }}$}

Kata esensi adalah suatu istilah penting yang menjelaskan tentang bagian utama. ${ }^{8}$ Laggas Paul menjelaskan bahwa esensi adalah inti. ${ }^{9}$ Dalam Kamus Besar Bahasa Indonesia menjelaskan bahwa esensi adalah hal yang pokok atau inti dan atau hakikat. Jadi esensi adalah hal yang utama, hal yang mendasar. Maka dalam konteks ini bahwa esensi adalah hal yang paling mendasar dalam kepemimpinan seseorang.

\section{$\underline{\text { Pemimpin }}$}

Sebelum memberikan pengertian dari kata pemimpin, penulis terlebih dahulu membuat klasifikasi dan klarifikasi dari kata pemimpin, kepemimpinan, memimpin dan pimpin. Kata pemimpin berarti orang yang memimpin. ${ }^{10}$ Kata kepemimpinan adalah terkait dengan perihal memimpin atau cara memimpin. Berikutnya arti kata memimpin adalah mengetuai atau mengepalai. Sedangkan kata pimpin yaitu dibimbing atau dituntun.

Atas dasar definisi di atas dapat dirumuskan bahwa pemimpin adalah orang yang ditunjuk oleh organisasi untuk mengepalai suatu organisasi yang ada. Itu berarti pemimpin tersebut mempunyai bawahan yang harus dipimpin,

${ }^{8}$ Alswang, J. and van Rensburg A, New English Usage Dictionary. (Randburg : Hodder \& Stoughton Educational 1999), 1995

${ }^{9}$ Lagass, Paul, The Columbia Encyclopedia. 6th ed. (New York, Detroit : Columbia University Press; Sold and distributed by Gale Group, t.t. )

${ }^{10}$ Hasan Alwi, Kamus Besar Bahasa Indonesia Edisi ke tiga, (Jakarta: Balai Pustaka, 2000), 874 
berdasarkan anggaran dan tata kelola yang ada dalam lembaga atau yayasan atau institusi tersebut.

\section{MENGENAL SEPINTAS SEJARAH KEPEMIMPINAN}

Dalam sepanjang sejarah kepemimpinan mencatat bahwa tidak ada satu kepemimpinan yang luput dari problematika hidup. Artinya semua pemimpin pernah mengalami permasalahan, baik permasalahan yang dilakukan oleh pemimpin atau pun yang dilakukan oleh yang dipimpin terhadap pemimpinnya. Inilah seluk-beluk kepemimpinan dari zaman ke zaman.

Sekarang kembali kepada pemimpin, apakah pemimpin mau mempengaruhi dunia sekitar, ataukah dunia sekitarlah yang mempengaruhi pemimpin. Stevri Indra Lumintang menjelaskan bahwa dalam kenyataanya dan sesuai dengan catatan sejarah, peradaban dunia ini sangat banyak dipengaruhi oleh para pemimpin. ${ }^{11}$ Karena pemimpin adalah figur yang menjadi contoh dan teladan bagi publik yang dipimpinnya. Namun pada kenyataannya bahwa dunia ini telah kehilangan identitas dan integritas pemimpin. Jadi hilangnya integritas bagi seorang pemimpin tidak hanya pada bidang-bidang yang sifatnya sekuler saja, melainkan muncul dan terjadi juga di kepemimpinan gereja yang mengakibatkan banyak jemaat tidak lagi percaya kepada pemimpin mereka. Hal ini dipertajam oleh Senjaya bahwa gereja pun telah dan sedang berada dalam krisis kepemimpinan. Gereja yang seharusnya menghasilkan pemimpin yang tinggi iman, tinggi ilmu dan tinggi pengabdian, malah terkontaminasi dengan berbagai masalah kepemimpinan. ${ }^{12}$

11 Stevri Indra Lumintang, Theologia kepemimpinan Kristen Theokrasi di tengah Sekularisasi Gereja Masa Kini, (Jakarta: Geneva Insani Indonesia, 2015), xix. Pengaruh buruk atau tidaknya kembali kepada pemimpin yang adalah figure bagi umat yang dipimpinnya. Apakah pemimpin berlaku buruk ataukah tidak buruk? Stevri menjelaskan bahwa pemimpin yang baik mempengaruhi dunia menjadi lebih baik, sebaliknya pemimpin yang buruk mempengaruhi dunia menjadi lebih buruk. Dan sejak mulanya peradaban dunia ini, tidak hentihentinya pemimpin yang muncul dan berperan buruk. Karena itu dunia ini sejak awalnya sampai saat ini, terus menerus dirusak oleh pemimpin yang buruk karena tidak berintegritas dan tidak berkomptensi.

${ }^{12}$ Sanjaya, Kepemimpinan ..., 17

Peneliti Kristen George Barna meyimpulkan hasil studinya selama 15 tahun tentang kehidupan gereja secara global dengan konklusi sebagai berikut: Gereja telah kehilangan pengaruhnya pada dunia ini karena absennya kepemimpinan yang efektif. (Informasi ini ada pada halaman dan judul buku yang sama) 


\title{
DASAR ALKITAB TENTANG ESENSI KEPEMIMPINAN
}

\author{
$\underline{\text { Alkitab PL Tentang Esensi Kepemimpinan }}$
}

Banyak teks Perjanjian Lama yang menjelaskan tentang kepemimpinan. Misalnya dalam Kitab Kejadian menceritakan tentang penciptaan alam semesta dan segala isinya. Kemudain Allah menciptakan manusia sekaligus memberikan mandat kepadanya agar bertangggungjawab terhadap semua ciptaan Tuhan yang ada. Pada pasal-pasal berikutnya menjelaskan hal yang sama terhadap manusia pertama supaya saling menolong satu sama lain. Maka istilah tanggungjawab itu menunjukkan pada kepemimpinan manusia pertama saat itu. Beberapa tokoh Perjanjian Lama yang menarik perhatian penulis adalah:

\begin{abstract}
Adam
Adam diberi tanggungjawab oleh Tuhan dengan mandat "berkuasalah atas ikan-ikan di laut, atas burung-burung di udara, dan atas segala binatang yang merayap di bumi" (Kej.1:28c). Penjelasan Petrus Octavianus "kekuasaan untuk memimpin yang ada pada manusia ia terima dari Allah, bukan inheren pada kemanusiaannya, sebab itu harus senantiasa dilaksanakan dalam ketaatan kepada Sumber Kekuasaan itu". ${ }^{13}$ Jadi esensi kepemimpinan dalam bagian ini adalah Adam bertanggungjawab terhadap semua ciptaan Tuhan atas dasar perintah Tuhan
\end{abstract}

\footnotetext{
${ }^{13}$ Petrus Octavianus, Alih Generasi dan ..., 5

Mandat kekuasaan yang diberikan oleh Allah berlaku atas makhluk-makhluk ciptaan yang lain, sedang dalam hubungan antar manusia, yang dikehendaki oleh Allah adalah relasi yang sepadan dan saling menolong (Kej. 2:18). Tetapi kemudian suasana Firdaus ini hilang karena pemberontakan Adam dan Hawa, mereka jatuh ke dalam dosa. Maka terjadi perubahan kepemimpinan dari hierarki kekuasaan kepemimpinan. Dari kekuasaan di bawah Allah, berubah menjadi kekuasaan kepemimpinan yang bersifat diktator, egoistis, demonis, dan destructiv. Mengapa demikian? Akar permasalahannya adalah karena dosa manusia, maka manusia mulai mengklaim bahwa kekuasaannya ada pada dirinya, itu sebabnya kecenderungan hati dan praktisnya tidak lagi taat kepada Tuhan.
} 


\section{Abraham}

Bagi Para Penulis Alkitab, Abraham tidak hanya mempunyai status historis saja tetapi sebagai gambaran tentang berbagai tema yang ada dalam Perjanjian Lama maupun Perjanjian Baru. Dalam kitab Kejadian, Abraham digambarkan sebagai seorang bapak leluhur yang kepadanya Allah memberikan janji-janji, dan dengannya Allah membuat sebuah "kovenan" yang sifatnya material dan spiritual (Kej.12:2,7; 13:14-15,17; 17:7,19,21). Berikutnya Abraham digambarkan sebagai teladan (Kej. 12:1-4; 17:1). Ketaatannya merupakan inti hubungannya dengan Yahweh. Leland Ryken menjelaskan bahwa Abraham sebagai penerima janji ilahi, sebagai teladan ketaatan dan iman, sebagai pensyafaat. Juga terlihat sebagai suami, paman, bapa. Serta pemimpin klan, Abraham menjadi diplomat bagi beberapa sosok agung, termasuk raja-raja dan imam Melkisedek. ${ }^{14}$

\section{Musa}

Dalam Keluaran 18 menjelaskan tentang rancangan tugasnya sendiri. Rancangan tugas sebaiknya mulai dari atas dan diteruskan melalui tingkattingkat lainnya dalam organisasi. Rancangan itu sederhana, jelas dan fleksibel. Maka dalam Keluaran 18:19-21, Musa memiliki tiga tanggung jawab utama: (1) membawa berbagai masalah orang banyak kepada Allah; (2) mengajar dan melatih mereka untuk melakukan pekerjaan yang akan mereka lakukan; (3) memilih pemimpin-pemimpin yang cakap untuk membantu dia menanggung beban kepemimpinan. ${ }^{15}$

\section{Musa Memberi perhatian kepada Allah}

Jhon Virgil menjelaskan bahwa Allah membentuk Musa menjadi pemimpin yang dapat digunakan-Nya. Musa berangkat ke Midian dan memiliki banyak waktu untuk merenunginya selama selama empat puluh tahun. Ketika Musa lewat semak yang menyala-nyala itu, ia siap mendengar

\footnotetext{
${ }^{14}$ Lelan Ryken, The Dictionary of Biblical Imagery, (Surabaya: Momentum, 2011), 1

${ }^{15}$ David Hocking, Rahasia Keberhasilan Seorang Pemimpin, 7 Hukum Kepemimpinan Rohani, (Yogyakarta: Yayasan Andi, 1996), 2-3
} 
Allah, dan diam untuk mendengarkan suara-Nya. ${ }^{16}$ Fakta yang ada acapkali sebagai pemimpin kurang menempatkan waktu bersekutu dengan Allah. Sibuk dan tidak menyisihkan waktu bersaat teduh dengan Allah. Maka seorang pemimpin yang baik adalah mempunyai komitmen yang utuh dengan berserah kepada Allah dalam hal dan dalam situasi apa pun.

\section{Musa jujur terhadap Allah}

Ketika Musa berjumpa dengan Allah di semak yang menyala-nyala itu, tidak ada lagi sikap sombong seperti ketika ia masih di Mesir. Musa lemah, dan ia tahu itu. Saat firman Allah datang kepadanya tentang ia akan membawa bangsa Israel keluar dari Mesir, respon Musa "siapakah aku ini" (Kel. 3:11). Sikap hati yang jujur tentang dirinya adalah hal yang penting, bahkan cikal bakal menjadi pemimpin yang dipercayakan oleh Tuhan.

\section{Musa mendambakan Allah}

Musa sungguh mendambakan Allah dalam hidupnya. Musa dan para tokoh Alkitab PL lainnya tentu memiliki sikap hati yang berbeda-beda dalam menghadapi setiap permasalahan yang ada. Permasalahan yang sifatnya internal maupun eksternal. Ada yang membawa permasalahannya kepada keinginan dirinya, kepada dewa-dewi yang tidak memberikan dampak positif bagi dirinya. Musa mempunyai sikap hati yang berbeda yakni memprioritaskan Allah setelah mengalami masa empat puluh tahun di padang belantara.

\section{$\underline{\text { Musa diremukkan Allah }}$}

Pada hakekatnya bahwa Allah tidak memaksakan kehendak-Nya terhadap Musa. Allah menunggu hingga Musa bersedia datang kepada-Nya "ketika dilihat Tuhan bahwa Musa menyimpang untuk memeriksanya, berserulah Allah di tengah-tengah semak duri itu kepadanya: Musa, Musa" (Kel.3:4) begitu Musa berpaling kepada Allah, ia dapat diremukan. Proses perumukan mencakup dua hal: kesombongan dan sikap mengandalkan diri

16 Jhon Virgil, Pengaruh Kekaguman Pengikut terhadap Ciri Pemimpin Gaya Kepemimpinan Situasi Kepemimpinan, (Jakarta: Yaki, 2007), 26 
yang tidak benar, disingkirkan, lalu sikap mengandalkan Allah yang sehat, dibangun. ${ }^{17}$

\section{Yosua}

Sesudah Musa meninggal, Tuhan berfirman kepada Yosua dan berkata kepadanya bahwa ia akan memimpin umat-Nya menuju tanah yang akan Tuhan berikan kepada mereka. ${ }^{18}$ Depertegas lagi dalam Kitab Ulangan 34:9 Yosua telah dipilih oleh Musa untuk menggantikannya. Dalam kepemimpinannya dapat dijelaskan bahwa "Yosua penuh dengan roh hikmat untuk kepemimpinan yang efektif, yakni: (1) kekuatan rohani dan semangat (Yosua 1:6,7,9); (2) merenungkan firman Allah setiap hari (Yos. 1:8); (3) ketaatan tanpa kompromi pada segala perintah Allah (Yos. 1:7,8).

Kepemimpinan Yosua bisa dijadikan contoh bagi kepemimpinan Kristen masa kini, yaitu membangun komunikasi kepada Tuhan secara kontinyu, merenungkan firman Allah dan melakukannya.

\section{Daud}

Allah memilih Daud sebagai pemimpin, bukan saja secara teologis Allah menetapkannya, melainkan juga Allah melihat kekuatan dari pribadi Daud sendiri. Hal ini dapat dicermati ketika Samuel datang untuk mengurapi salah seorang anak Isai untuk menjadi raja Israel, Ia memandang Eliab dan berpikir "sungguh di hadapan Tuhan sekarang berdiri yang diurapi-Nya" (1 Sam. 16:6). Akan tetapi Allah menjawab: "janganlah pandang parasnya atau perawakan yang tinggi, sebab Aku telah menolaknya. Bukan yang dilihat manusia yang dilihat Allah; manusia melihat apa yang di depan mata, tetapi Tuhan melihat hati" (ayat 7). ${ }^{19}$

Kepemimpinan Kristen tidak hanya melihat kharisma atau kepribadian yang besar, karena bisa jadi tampilan luar saja. Karena itu kepemimpinan harus berlandaskan pada apa kata Tuhan bagi pemimpin. Bukan kata hati nurani bagi pemimpin untuk menjadikan pemimpin. Maka beberapa syarat yang menjadi pemimpin efektif adalah:

\footnotetext{
${ }^{17}$ Jhon Virgil, Pengaruh Kekaguman Pengikut terhadap..., 27

${ }^{18}$ David Hocking, Rahasia keberhasilan seorang pemimpin ..., 4

${ }^{19}$ Jhon Virgil,Pengaruh kekaguman pengikut terhadap ..., 6
} 


\section{Daud membuka penghalang dalam dirinya ${ }^{20}$}

Kehidupan Daud telah mendemonstrasikan praktek mengevaluasi tentang kekuatan dan kelemahan pribadinya, serta memperbaiki diri. Contoh sikapnya terhadap Goliat. Sekalipun Daud belum mempunyai pengalaman dalam bertempur, tetapi Daud menggunakan pengalaman penggembalaan terhadap kambing domba dalam mempersiapkan diri. Sisi lain Daud telah belajar menggunakan ketapel, ia juga pernah menghadapi serangan singa dan beruang. Dari pengalaman ini dijadikan sebagai kekuatan dalam dirinya mengalahkan Goliat. Sisi lain yang tidak diabaikan adalah adanya intervensi Tuhan bagi Daud dalam berperang.

\section{Daud membuka penghalang dalam diri orang ${ }^{21}$}

Begitu seorang pemimpin membuka penghalang, hal-hal luar biasa akan terjadi. Sebelum Daud tampil, seluruh pasukan Israel berdiri ketakutan menghadapi bangsa Filistin. Mereka berjaga-jaga di lembah Elah dan mendengarkan intimidasi Goliat siang malam selama empat puluh hari, dan apakah yang diperkuat oleh Saul, pemimpin mereka? Ia bersembunyi. Saul sendirilah penghalang yang menghalangi seluruh pasukan Israel itu. Namun demikian Daud tampil dan mendemonstrasikan kepemimpinan yang membuka penghalang yang menutupi seluruh pasukan Israel itu. Orang Filistin melihat, bahwa pahlawan mereka telah mati, sebagai dampaknya mereka takut dan lari. Maka bangkitlah orang-orang Israel dan Yehuda, bersorak-sorak dan mengejar serta membunuh orang Filistin (1 Sam. 17:51-52).

\section{Daud membuka penghalang bagi seluruh bangsanya ${ }^{22}$}

Daud terus mengandalkan Tuhan dalam kepemimpinannya. Ia diberikan kesempatan untuk membuka penghalang bagi seluruh bangsanya. Dengan kepemimpinan Daud, akhirnya bangsa Israel mulai percaya bahwa bangsanya menang dalam peperangan karena campur tangan Tuhan. Dari kemenangan ini Allah juga berkenan memberikan wilayah-wilayahnya kepada bangsa Israel untuk mendudukinya dan juga menampung kekuasaan Edom, Moab, Amnon dan Zobah.

\footnotetext{
${ }^{20}$ Ibid., 30

${ }^{21}$ Jhon Virgil, Pengaruh kekaguman pengikut terhadap ..., 30

${ }^{22}$ Ibid., 30
} 


\section{PERSPEKTIF PARA TOKOH TENTANG SYARAT ESENSI KEPEMIMPINAN}

Setiap elemen dari sebuah organisasi apa pun tentu ada syarat, demikian juga dengan kepemimpinan, karena dari syarat ini apakah seorang pemimpin dapat memenuhi syarat dalam kepemimpinannya ataukah tanpa syarat seorang pemimpin bisa memimpin dengan baik? Jadi penulis akan mengemukakan beberapa syarat mendasar yang perlu dilakukan oleh seorang pemimpin pastoral antara lain:

\section{$\underline{\text { Memiliki Karakter yang Baik (Character) }}^{23}$}

Di dalam realitas kehidupan sehari-hari pemimpin selalu menjadi tumpuan harapan komunitasnya, sekaligus sasaran ketidak-puasan mereka terhadap kepemimpinannya karena karakternya cenderung tidak sesuai dengan apa yang disampaikan. ${ }^{24}$ Dalam Kamus Besar Bahasa Indonesia, arti kata karakter adalah sifat-sifat kejiwaan, akhlak atau budi pekerti yang membedakan dengan orang lain. ${ }^{25}$ Willie Louis Kornelius menjelaskan "Character is foundational for good leadership". ${ }^{26}$ Yakob Tomatala menjelaskan bahwa "karakter adalah hakikat, sifat dan ekspresi kepribadian seseorang yang dinyatakan melalui pembicaraan serta perilaku dalam lingkungan atau konteks di mana dia hidup". ${ }^{27}$ Jadi karakter adalah salah satu sifat manusia yang ada dalam dirinya, maka otomatis karakter tersebut ada dalam diri setiap pemimpin. Karakter adalah dasar dalam kehidupan seorang pemimpin. Untuk mengimplementasiakan karakter yang baik bukan hanya pada waktu dilihat orang banyak, melainkan dalam situasi tidak ada orang lain pun, seorang pemimpin tetap mengimplementasikan karakternya yang baik. Itu sebabnya bagi seorang pemimpin sungguh mempertaruhkan nilai-nilai karakternya. Joyce Meyer menjelaskan karakter seorang pemimpin dalam beberapa aspek:

${ }^{23}$ Willie Louis Kornelius, Breakthrough in leadership, (Tanpa Kota: International Bible Society, 2010), 5

${ }^{24}$ Drs. E.B. Surbakti, Manajemen dan Kepemimpinan Hati Nurani, (Jakarta: PT Gramedia, 2012), 107

${ }^{25}$ W.J.S. Poerwadarminta, Kamus Besar Bahasa Indonesia, (Jakarta: Balai Pustaka, 2013), 521

${ }^{26}$ Willie Louis Kornelius, Breakthrough in ..., 5

${ }^{27}$ Yakob Tomatala, Pemimpin yang handal, (Jakarta: Jafray, 1996), 41 


\section{1) Kehidupan Rohani}

Orang-orang yang ingin menjadi pemimpin harus memiliki karakter yang baik dalam kehidupan rohaninya. Artinya mereka harus memiliki hubungan pribadi yang dalam dengan Allah.

\section{2) Kehidupan pribadi}

Orang yang ingin menjadi pemimpin harus memiliki karakter yang baik dalam dirinya. Artinya apa yang dikatakan harus sesuai dengan tindakannya.

\section{3) Kehidupan Sosial}

Seorang pemimpin yang baik harus membangun hubungan komunikasi yang baik kepada siapa saja. Artinya dalam komunikasi harus ada empati dan simpati terhadap semua orang. Ini berarti seorang pemimpin tidak membuat perbedaan, semuanya sama di mata seorang pemimpin.

\section{4) Kehidupan pernikahan dan Keluarga}

Ia harus memperlakukan pasangannya dengan benar, memenuhui tanggung jawab keluarga, meluangkan waktu dengan anak-anak, menentukan skala prioritas dengan benar, memastikan bahwa kehidupan seksnya sehat dan menjaga rumahnya agar tetap teratur dan tertib.

\section{5) Kehidupan keuangan}

Seorang pemimpin harus jujur dengan keuangan, mengingat uang adalah akar dari segala kejahatan jika tidak diatur dengan baik dan penuh tanggung jawab.

\section{6) Perkataan}

Bagi seorang pemimpin bahwa perkataan adalah bagian yang sangat penting. Seseorang akan kehilangan karakter jika ia membumbu-bumbui sebuah kisah sehingga kisah itu tidak lagi mengandung kebenaran. Atau menyampaikan kebenaran secara berlebihan hanya untuk memenuhi apa yang diinginkan oleh dirinya supaya kelihatan tidak buruk karakternya. ${ }^{28}$

\section{$\underline{\text { Integritas (Integrity) }}^{29}$}

Banyak judul buku, jurnal dan artikel tentang integritas kepemimpinan yang terus menyoroti kepemimpinan dari abad ke abad, namun lagi-lagi pada faktanya bahwa buku hanyalah buku, artinya hanya sebuah tulisan yang sifatnya memuaskan akademis semata, dan tanpa mempraktekkan nilai-nilai

${ }^{28}$ Joyce Meyer, Pemimpin yang Sedang Dibentuk Hal-hal Penting untuk Menjadi Seorang Pemimpin yang Berkenan di Hati Allah, ( Jakarta: Imanuel, 2005), 258-264

${ }^{29}$ Willie Louis Kornelius, Breakthrough in ..., 25 
dari sebuah tulisan dalam kehidupan, baik yang menulis atau pun yang membaca tulisan. Ini bukanlah fakta yang baru muncul, melainkan telah muncul dari para toko-toko Alkitab, toko gereja dari zaman ke zaman telah kehilangan integritas kepemimpinan.

Apa itu integritas? Hasan Alwi menjelaskan integritas adalah mutu, atau sifat, keadaan yang menunjukkan kesatuan yang utuh sehingga memiliki potensi dan kemampuan yang memancarkan kewibawaan atau kejujuran. ${ }^{30}$ Erry Riyana berpendapat bahwa integritas adalah tentang komunikasi (pernyataan) yang harus sesuai dengan tindakan. ${ }^{31}$ Sendjaya menegaskan integritas adalah modal utama seorang pemimpin, namun sekaligus modal yang paling jarang dimiliki oleh pemimpin. ${ }^{32}$ Pendapat Surbakti demikian: "Integritas berkaitan dengan ketulusan hati, kejujuran, pendirian dan keutuhan diri. Maka maknanya adalah seorang pemimpin mampu mendorong dan melakukan yang terbaik dalam kepemimpinannya."33 Oleh karena itu tanpa adanya integritas, maka kepemimpinannya patut dipertanyakan karena pemimpin seperti ini sulit mengharapkan akan prestasinya.

Dengan demikian seorang pemimpin perlu memiliki sifat integritas yang jujur, transparan dan berlaku adil bagi konteks di mana dia berada. Karena seorang pempimpin berada pada konteks yang plural, maka harus berjaga dan berwaspada antara perkataan dengan tindakan (satu kata satu tindakan).

\section{$\underline{\text { Rendah Hati (Humility) }}^{34}$}

Rendah hati adalah sebuah pekerjaan yang berat dalam hidup manusia, karena setiap manusia yang berada dalam dunia ini termasuk pemimpin Kristen mempunyai kecenderungan tidak rendah hati. Lawan kata dari rendah hati

\footnotetext{
${ }^{30}$ Hasan Alwi, Kamus Besar ..., 437

${ }^{31}$ Erry Riyana Hardjapamekas, Esensi Kepemimpinan Mewujudkan Visi Menjadi Aksi, (Jakarat: Gramedia, 2000), 37

${ }^{32}$ Sendjaya, kepemimpinan ..., 62

Peneliti kepemimpinan James Kouzes dan Barry Posner melaporkan hasil riset mereka selama 20 tahun dari survey terhadap ribuan kaum professional dari empat benua bahwa karakteristik nomor satu yang paling kritis dalam kepemimpinan adalah integritas. Integritas adalah sebuah komoditas kepemimpinan yang sangat langka, bahkan hampir punah. Integritas bukan hanya milik pemimpin saja melainkan milik semua orang. Terbukti bahwa banyak remaja dan muda-mudi telah melakukan hubungan seks di luar pernikahan, bukankah ini satu tanda bukti hilangnya nilai integritas manusia.

-33 E.B. Surbakti, Manajemen dan Kepemimpinan Hati Nurani, (Jakarta: PT Gramedia, 2012), 115

${ }^{34}$ Willie Louis Kornelius, Breakthrough in ..., 43
} 
adalah kesombongan. Kata Yesus kepada para murid-Nya: "Barang siapa meninggikan diri, ia akan direndahkan, dan barang siapa merendahkan diri ia akan ditinggikan (Mat. 23:12; Luk. 14:11). Surbakti menjelaskan pemimpin yang rendah hati akan ditinggikan oleh komunitasnya, sedangkan pemimpin yang tinggi hati akan direndahkan komunitasnya. Bagaimanapun pemimpin yang congkak, sombong dan angkuh pasti akan mendapatkan tantangan yang keras dari komunitasnya. Sejarah perjalanan umat manusia membuktikan tidak sedikit pemimpin yang kurang berkenan di dalam hati komunitasnya, akhirnya tumbang di tengah jalan. ${ }^{35}$

Atas dasar pernyataan ini, setiap pemimpin pasti memiliki kelemahankelemahan hidupnya dalam hal memimpin. Baik itu sombong, angkuh, tinggi hati. Jika mau diteladani hidupnya oleh komunitas yang dipimpin maka semestinya mengikuti teladan dari Tuhan Yesus Kristus yang tidak sombong dan tidak angkuh dalam kepemimpinan bersama dengan murid-muridNya.

\section{$\underline{\text { Ketaatan }}$ (Obedience) $^{36}$}

Aspek ketaatan bagi seorang pemimpian dilihat dari ketaatannya kepada Tuhan yang telah memanggil dia. Karena sumber ketaatannya adalah dari dan melalui Tuhan. Tanpa Tuhan memberikan ketaatan kepada seorang pemimpin, maka dia akan menjadi pemimpin yang taat karena takut kepada pimpinan yang lebih tinggi kedudukannya. Ataukah takut kehilangan jabatan karena bawahan atau atasannya telah memberikan sogokan berupa material yang lebih kepadanya. Apakah ini ketaatan seorang pemimpin? Dalam pengamatan penulis bahwa tipe pemimpin seperti ini tidak akan bertahan lama dalam kepemimpinannya. Karena yang dia lakukan untuk kepetingan dirinya sendiri ketimbang kepentingan Tuhan. Maka ketaatan kepada Tuhan adalah melului respon atau tanggapan terhadap Tuhan. Seperti pernyataan Willie Louis "according to scripture, a fundamental factor of the quality of this life and of the next is our response to god's initiatives. Response is unavoidable; we may ignore, resist or reject God's initiatives and requirements. ${ }^{37}$

Memang benar bahwa dalam sejarah kepemimpinan dari bidang organisasi apa pun semuanya telah mengalami problem yang sama yaitu ada pemimpin yang benar-benar taat, ada pemimpin yang taat karena ada kepentingan lainnya yang terselubung, ada pemimpin yang tidak taat karena

\footnotetext{
${ }^{35}$ E.B. Surbakti, Manajemen dan Kepemimpinan ..., 117

${ }^{36}$ Willie Louis Kornelius, Breakthrough in ..., 63

${ }^{37}$ Ibid.
} 
tidak mau diatur oleh sejumlah sistem yang bagi dia tidak sesuai dengan pengetahuan yang dimiliknya. Sebagai contoh dalam Alkitab: Cerita mengenai Sadrakh, Mesak, Abednego, disuruh oleh Raja Nebukadnezar untuk menyembah patungnya yang telah didirikan olehnya. Secara faktual bahwa ketiga orang saleh ini tidak mau taat terhadap perintahnya. Hal ini dilakukan oleh karena ketiga orang saleh ini telah memiliki pengetahuan yang benar kepada Allah yang telah menciptakan langit dan bumi. ${ }^{38}$ Itu sebabnya mereka lebih memilah dan memilih menyembah kepada Tuhan yang hidup ketimbang menyembah kepada patung yang tidak bernafas dan tidak memberikan manfaat bagi ketiga orang saleh ini. Inilah salah satu fakta-fakta yang terjadi dalam kepemimpinan yang ada dalam Alkitab. Sehingga bisa menjadi acuan untuk melihat aspek ketaatan seorang pemimpin pada masa sekarang. Apakah dia benar-benar taat kepada Tuhan ataukah taat kepada pemimpin karena memiliki sejumlah motivasi yang terselubung. Apapun bentuk problematik dalam kepemimpinan seseorang karena tidak taat, Alkitab mengajarkan supaya terus taat kepada Tuhan dan taat kepada pemimpin yang takut kepada Tuhan.

\section{$\underline{\text { Komitmen }}$}

Komitmen bagi seorang pemimpin pastoral sangat dibutuhkan dalam kepemimpinannya. Karena komitmen adalah salah satu bagian dari integritas seorang pemimpin supaya semua komunitas yang dipimpinnya dibawa pada suatu perubahan yang mensejahterakan. Sejahtera atau tidak, terletak pada pundak pemimpin. Fakta kekinian banyak pemimpin yang berjanji namun tidak menepati janjinya dengan baik. Malah sebaliknya menggunakan kepemimpinan sebagai kesempatan untuk menguntungkan pribadi, kelompok, dan siapa yang dekat dengan dirinya sebagai pemimpin.

Untuk itu pengambilan sebuah komitmen, baik itu komitmen untuk tidak melakukan penggelapan keuangan, komitmen untuk tidak melakukan penyimpangan seksualitas, komitmen merahasiakan permasalahan orang yang dipimpinnya, komitmen untuk tidak menyampaikan berita bohong (hoak), komitmen untuk mengembangkan diri, baik dari sumber daya manusia maupun hal lainnya. Juga komitmen untuk membangun hubungan pribadi kepada Tuhan. Sejumlah uraian tentang pengambilan komitmen bagi seorang pemimpin pastoral yang ada korelasinya kepada Tuhan dijelaskan oleh Ronald W. Leigh demikian

\footnotetext{
${ }^{38}$ Lelan Ryken, The Dictionary of Biblical ..., 1054
} 
1) Komitmen menerima keselamatan

2) Komitmen untuk kasih yang mendalam kepada Alkitab

3) Ketaatan kepada Tuhan Yesus Kristus dalam segala aspek kehidupan

4) Ketaatan kepada Roh Kudus

5) Pengakuan akan dosa dan berbagai kekurangan

6) Usaha menjadi seperti sifat Kristus

7) Penyembahan kepada Allah dengan tulus

8) Terus berdoa dan bersyukur kepada Tuhan Yesus Kristus

9) Kesetiaan untuk segra mengaku dosa. ${ }^{39}$

\section{Nilai}

Nilai-nilai pribadi sangat dibutuhkan dalam kepemimpinan, karena nilainilai adalah hal yang sifatnya umum dan itu tidak bisa terpisah dengan keberadaan seorang pemimpin. Jerry C. Wofford menjelaskan nilai-nilai pribadi memancar dari inti kepemimpinan yang mengubahkan. Nilai-nilai seperti kebenaran, kasih dan stabilitas meneguhkan praktek-praktek seperti penentuan visi, penetapan arah masa depan dan mobilisasi. Oleh karena perubahan, nilai-nilai inti berfungsi sebagai baling-baling internal yang memberikan patokan untuk menetapkan arah yang benar. ${ }^{40}$

\section{Pemberdayaan}

Istilah pemberdayaan berasal dari kata daya yang mendapat awalan ber, yang menjadi kata berdaya artinya memiliki atau mempunyai daya. Daya artinya memiliki kekuatan. Jadi pemberdayaan adalah membuat sesuatu menjadi berdaya, mempunyai daya, mempunyai kekuatan. Pemberdayaan adalah mempunyai kecakapan/kemampuan, kekuasaan. ${ }^{41}$

Willie berpendapat:

When Jesus commissioned his disciples to reach the word with his message in Matthew 28, he provided helpful principles for empowerment. Jesus commissioned them to use his power for specific purposes, which he clearly defined. He assured them that he would be there to back them up. He prepared them before

39 Ronal W. Leigh, Melayani dengan Efektif, (Jakarta: BPK Gunung Mulia, 2011), 12

40 Jerry C. Wofford, Kepemimpinan Kristen yang Mengubahkan, (Yogyakarta: Yayasan Andi, 2001), 31

${ }^{41} \mathrm{htt} / /$ suniscom.50webs.com/32\%20konsep\%20pemberdayaan\%partisipasi\%20kelemb agagaan.pdf 
delegating the authority to them. He held them accountable for how they used his power. ${ }^{42}$

Yesus menugaskan murid-murid-Nya untuk mencapai firman dengan pesannya di Matius 28. Sebagai pemberdayaan, Yesus menugaskan mereka supaya menggunakan kekuatannya untuk tujuan firman. Dia meyakinkan mereka bahwa Dia akan berada di sana untuk mendukung mereka. Dia mempersiapkan mereka sebelum mendelegasikan wewenang kepada mereka. Dan meminta pertanggungjawaban dari para murid. Jadi pemberdayaan bagi seorang pemimpin adalah mempunyai kekuasaan, kekuatan dan kemampuan untuk memberikan tanggung jawab kepada bawahannya supaya bebas mengekspresikan kemampuannya dalam bidang atau keahlian yang dimilikinya. Itu berarti pemberdayaan bukan hanya didiktator oleh pemimpin untuk memenuhi kebutuhan pemimpin, melainkan demi kebutuhan Tuhan melalui pemimpin.

\section{Visi}

Hasan Alwi mendefinisikan istilah visi dalam tiga kategori yang mempunyai hakekat yang sama: (1) "kemampuan untuk melihat pada inti persoalan"; (2) "Memiliki pandangan atau wawasan ke depan”; (3) kemampuan untuk melihat sesuatu yang tidak tampak melalui kehalusan jiwa dan ketajaman penglihatan ". ${ }^{43}$ Henk Ten Napel menjelaskan istilah visi dari bahasa Latin visio atau videre, artinya melihat. Dari bahasa Inggris vission, penglihatan. Kata vissionary artinya hanya dalam khayalan atau orang yang berkhayal. ${ }^{44}$ Erry Riyana berpendapat bahwa visi adalah menyusun programprogram dengan hati-hati untuk jangka pendek, jangka menengah, dan jangka panjang. ${ }^{45}$

${ }^{42}$ Willie Leadership ..., 125

${ }^{43}$ Hasan Alwi, Kamus Besar ..., 1262

${ }^{44}$ Henk Ten Napel, Kamus Teologi Inggris-Indonesia, (Jakarta: Bpk Gunung Mulia, 2002), 327

45 Erry Riyana Hardjapamekas, Esensi kepemimpinan ..., 13. Selanjutnya Erry beranggapan bahwa demi tercapainya visi, maka membutuhkan rekrutmen anggotanya untuk mendukung visi yang dimaksud. Maka perlu ada syarat-syarat yang harus dilakukan oleh semua komunitas sebagai pendukung visi, antara lain

a) Seorang bawahan harus memiliki integritas

b) Seorang bawahan harus mempunyai motivasi yang tulus dalam mendukung visi yang ada 
Mengacu pada pernyataan-pernyataan ini, maka penulis dapat merumuskan bahwa visi adalah sebuah pernyataan dari seorang pemimpin, dan pernyataan tersebut belum terjadi atau terlaksana, sehingga membutuhkan komunitas internal maupun komunitas eksternal untuk mendukung visi yang ada dalam diri pemimpin dalam memimpin sebuah organisasai, baik yang sifatnya sekuler atau yang sifatnya religius. Maka organisasi dalam bentuk apapun pasti mempunyai visi, karena dari visilah orang bisa mencapai target keberhasilan. Ini berarti visi hanya bersifat impian atau idealis, yang belum terjadi. Jika visi itu terjadi, maka disebut sebgai visi yang factual.

Jerry C. Wofford menjelaskan bahwa sebuah visi adalah suatu keadaan masa depan yang ideal atau unik yang terkristal menjadi suatu gambaran yang jelas sejernih kristal tentang kondisi yang diinginkan oleh sebuah gereja. Visi ini menunjukkan suatu pandangan sekilas dari masa depan yang kita inginkan dan yang kita pikirkan seharusnya demikian. Selanjutnya Jerry mengutip pernyataan Jhonatan Swift dalam bukunya bahwa Visi adalah seni melihat halhal yang yang tak kasat mata. ${ }^{46}$

\section{Mentoring}

Mentoring adalah suatu proses yang luar biasa. Di satu pihak, sang mentor harus rela menerima hal baru dan membuang hal-hal indah yang dimilikinya namun sudah usang. Di pihak lain, sang mentor harus belajar untuk terbuka menjelaskan pengalaman-pengalaman pribadinya, termasuk kegagalankegagalan yang memalukan. Tanpa kesediaan untuk saling percaya, maka tidak akan muncul proses mentoring yang sejati yang mempercepat berbagai pengembangan orang-orang yang produktif. ${ }^{47}$ Tugas mentoring dilakukan oleh

c) Seorang bawahan harus mempunyai kapasitas atau kemampuan dalam menumbuhkembangkan visi yang ada

d) Seorang bawahan harus mempunyai pemahaman atau pengertian yang sama dalam memahami visi dan perlu diimplementasikan

e) Seorang bawahan harus juga mempunyai pengetahuan yang cukup, agar bisa terlaksananya visi yang ada

f) Seorang bawahan harus juga mempunyai pengalaman pribadi dalam mendukung visi yang dimaksud.

Erry memberikan analogi yang cukup baik untuk ditumbuhkembangkan tanpa A maka B akan berbahaya. Tanpa $\mathrm{C}$ maka $\mathrm{D}$ terbatas. Tanpa $\mathrm{D}$ maka $\mathrm{E}$ tidak berarti. Tanpa $\mathrm{E}$ maka $\mathrm{F}$ menjadi buta. F mudah diperoleh dengan mudah digunakan hanya oleh yang memiliki kualitas A sampai dengan $\mathrm{E}$

${ }^{46}$ Jerry C. Wofford, kepemimpinan Kristen ..., 9

47 Robby I Chandra, Pemimpin dan Mentoring dalam Organisasi. (Jawa Barat: Generasi info media, 2006), iii. Robby Chandar menjelaskan lebih lanjut dengan mengutip 
pemimpin yang harus mempunyai kualifikasi diri, yang punya jam terbang alias punya banyak pengalaman pengabdian, baik kepada Tuhan, kepada lembaga, bahkan kepada organisasi lainnya, yang kemudian akan membentuk dia dan bisa memonitor bawahannya dengan baik. Itu sebabnya bagi mentor, tidak hanya mempunyai kualifikasi diri dalam hal pelayanan saja, melainkan harus juga punya wawasan yang luas, punya keterbukaan diri, punya kepercayaan diri, jujur terhadap dirinya sendiri bahwa orang yang dimentoring bukan supaya dirinya mendapat pujian, mendapat imbalan berupa material dan lain-lain, melainkan pusat pengabdian mentoringnya hanya dan kembali kepada Tuhan.

Istilah mentoring dalam kepemimpinan adalah sebuah istilah yang cukup populer. Namun yang menjadi kendala adalah bukan soal istilahnya, tetapi bagaimana agar istilah tersebut terbentuk, tertanam dan berbuah dalam diri seorang pemimpin, sehingga tanpa berbicara mentoring pun, masa atau komunitas yang dipimpin telah melihat hasil atau buah dari pemimpin yang punya tugas sebagai mentoring. Mentoring juga bukan hanya bertugas menyelesaikan persoalan orang lain, melainkan menumbuh-kembangkan potensi diri dari massa yang dimentoring oleh seorang pemimpin pastoral. Tentang mentoring pengembangan potensi pribadi mentoring atau yang dimentoring merupakan pekerjaan utama tiap-tiap orang.

Joyce Meller menjelaskan bahwa kita semua memiliki potensi, tetapi kita tidak akan pernah melihat potensi tersebut terwujud sebelum kita beriman kepada Allah dan yakin bahwa kita dapat melakukan apa saja yang Ia katakan bisa kita lakukan di dalam firman-Nya. ${ }^{48}$ Syarat-syarat yang telah dituliskan pada bagian di atas telah menunjukkan adanya kesinambungan. Untuk syarat lain, penulis kutip dari Surbakti dalam bentuk diagram. ${ }^{49}$

sejumlah buku menarik yang dikarang oleh para pakar mengenai definisi mentoring. Paul Stanley dan Robert Clinton berpendapat bahwa mentoring adalah suatu pengalaman relasional yang melaluinya seseorang memberdayakan orang lain dengan berbagai macam sumber daya yang telah Allah berikan. Menurut Jhon C. Crosby mentoring adalah pikiran yang dapat dipetik dan dijadikan sebagai tempat bersandar dan suatu tendangan di bokong. Menurut Chip R Bell, mentoring adalah seseorang membantu orang lain untuk belajar sesuatu, dan bila proses tadi tidak terjadi, maka pembelajarannya menjadi kurang baik, lebih lamban, atau bahkan sama sekali tidak akan terjadi.

${ }^{48}$ Joyce Meyer, Pemimpin yang sedang di bentuk ..., 13

${ }^{49}$ E.B. Surbakti, Manajemen dan Kepemimpinan ..., 118 


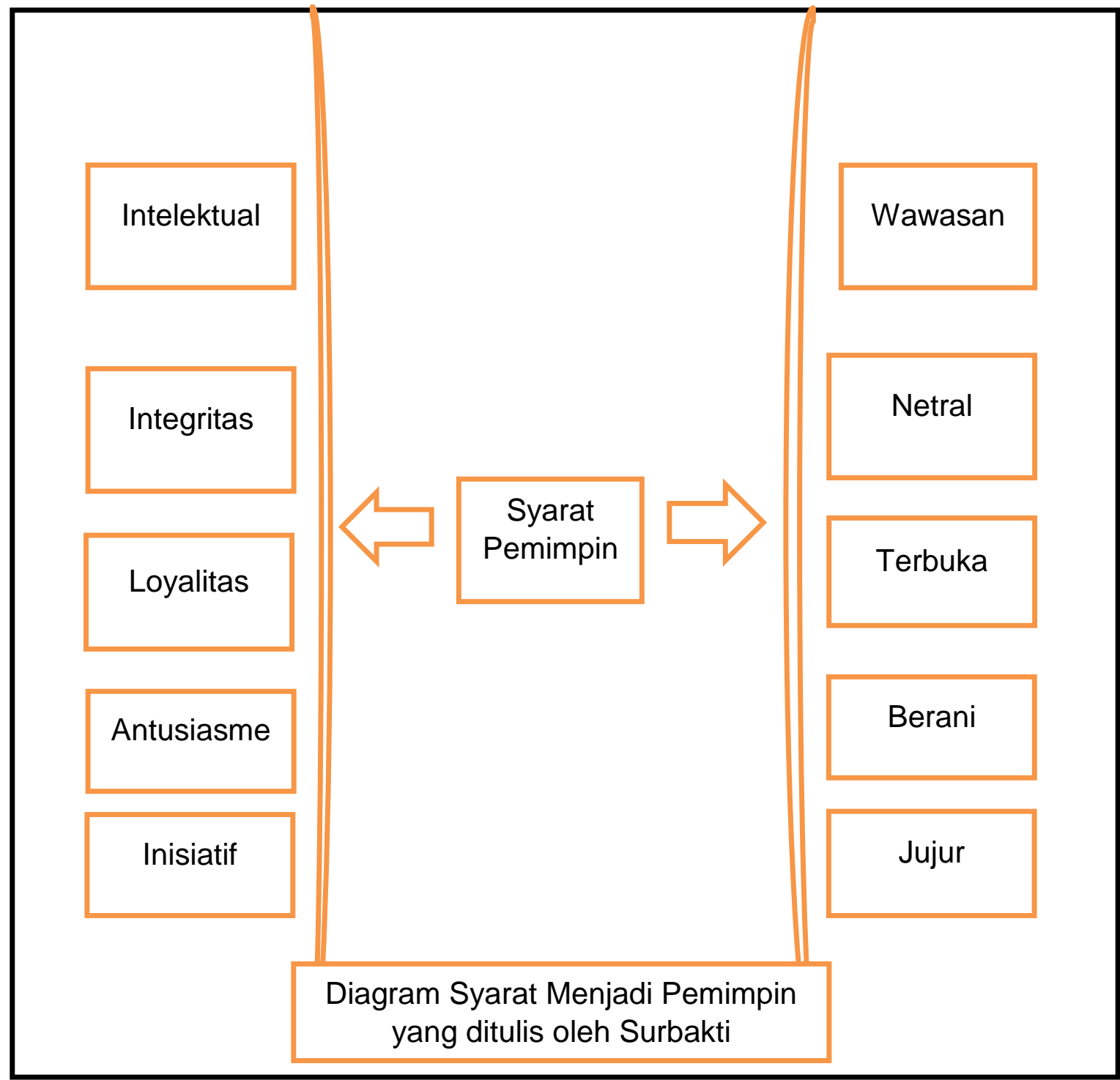

\section{SIMPULAN}

Penulis menyimpulkan bahwa memang kepemimpinan di abad postmodern ini telah mengalami krisis yang sangat signifikan yang merambat pada semua elemen dalam bidang kehidupan manusia, mengapa tidak? Karena 
para pemimpin lebih kepada kepentingan pribadi, keluarga, kelompok dan komunitas yang mendukungnya sebagai pemimpin. Yang lebih ironisnya adalah massa atau komunitas yang tadinya mendukung, namun ada hal-hal teknis yang kemudian berbeda pendapat antara massa atau komunitasnya dengan pemimpinnya. Sebagai reaksinya seorang pemimpin langsung mengambil keputusan dengan cara memecat. Maka dalam tulisan-tulisan sebelumnya dalam makalah ini secara gamblang telah menjelaskan bahwa krisis ini bukan hanya terjadi pada kepemimpinan yang sekuler saja, melainkan terjadi pada kepemimpinan gereja, yayasan bahkan lembaga Kristen lainnya juga telah mengalami krisis yang begitu berbahaya bagi kepemimpinan sekarang maupun pada kepemimpinan yang akan datang. Jika tidak segera dibuat standar pembaharuan-pembaharuan di dalamnya, tentu akan memunculkan permasalah-permasalahan yang baru lagi.

Dari seluruh pemaparan di atas, maka berikut adalah beberapa rekomendasi penulis:

1) Seorang pemimpin mengupayakan dirinya supaya tidak diktator, otoriter, menang sendiri, bahkan menganggap orang lain tidak berarti dalam kepemimpinannya. Pemimpin harus menyadari bahwa tanpa massa/komunitas maka tidak ada pemimpin. Itu sebabnya antara pemimpin dan yang dipimpin harus memahami bahwa keduanya saling membutuhkan, dan masing-masing membangun kebersamaan dalam garis firman Allah.

2) Masing-masing pemimpin perlu mengevaluasi diri, baik dari kepemimpinannya, sifatnya, karakternya, supaya tidak mengulangi hal yang salah lagi.

3) Pemimpin membuka dirinya untuk mendapat evaluasi dari komunitasnya.

4) Perlu belajar terhadap keberhasilan pemimpin lain di luar organisasinya yang dipimpin

5) Terus mempertahankan nilai-nilai positif dalam kepemimpinannya

6) Pendampingan atau mentoring perlu ditingkatkan kepada komunitas sesuai dengan visi misi yang ada 


\section{DAFTAR PUSTAKA}

Siringo-ringo, V.M,

2013 Theologi Perjanjian Lama, Sejarah, Metode dan Pokok-pokok Theology Perjanjian Lama. Yogyakarta: Yayasan Andi

Hokema, Anthony A.

2008 Manusia Ciptaan Menurut Gambar Allah. Surabaya: Momentum

Leahy, Louis,

1985 Manusia Sebuah Misteri Sintesa Filosofis tentang Makhluk Paradoksal. Jakarta: PT Gramedia

Surbakti, E.B.,

2012 Manajemen dan Kepemimpinan Hati Nurani. Jakarta: PT Gramedia

Octavianus, Petrus

t.t. $\quad$ Alih Generasi dan Kepemimpinan dalam Garis Firman Allah. Batu: Petrus Octavianus Institut

Sendjaya,

2004 Kepemimpinan (Konsep, Karakter, Kompetensi) Kristen Menjadi Pemimpin Kristen yang Efektif di tengah Tantangan Arus Zaman. Yogyakarta: Kairos Books

J. Alswang, and van Rensburg A

1999 New English Usage Dictionary. Randburg : Hodder \& Stoughton Educational

Paul, Lagass, 1987

The Columbia Encyclopedia. 6th ed. New York, Detroit : Columbia University Press; Sold and distributed by Gale Group

Alwi, Hasan,

2000 Kamus Besar Bahasa Indonesia Edisi ke tiga. Jakarta: Balai Pustaka 
Lumintang, Stevri Indra,

2015 Theologia kepemimpinan Kristen Theokrasi di tengah Sekularisasi Gereja Masa Kini. Jakarta: Geneva Insani Indonesia

Ryken, Lelan,

2011 The Dictionary of Biblical Imagery. Surabaya: Momentum

David Hocking,

1996 Rahasia Keberhasilan Seorang Pemimpin, 7 Hukum

Kepemimpinan Rohani. Yogyakarta: Yayasan Andi

Jhon Virgil,

2007 Pengaruh Kekaguman Pengikut terhadap Ciri Pemimpin Gaya

Kepemimpinan Situasi Kepemimpinan. Jakarta: Yaki

Willie Louis Kornelius,

2010 Breakthrough in leadership. Tanpa Kota: International Bible Society

E.B. Surbakti,

2013 Manajemen dan Kepemimpinan Hati Nurani. Jakarta: PT Gramedia

Joyce Meyer,

2005 Pemimpin yang Sedang Dibentuk Hal-hal Penting untuk

Menjadi Seorang Pemimpin yang Berkenan di Hati Allah.

Jakarta: Imanuel

Erry Riyana Hardjapamekas,

2000 Esensi Kepemimpinan Mewujudkan Visi Menjadi Aksi. Jakarta: Gramedia

Ronal W. Leigh,

2011 Melayani dengan Efektif. Jakarta: BPK Gunung Mulia

Jerry C. Wofford,

2001 Kepemimpinan Kristen yang Mengubahkan. Yogyakarta:

Yayasan Andi 